\title{
STRATEgic PlanNing FOR HUMAN RESOURCES IN Hotels: A Field STUdy ON A SAMPle OF Five STAR Hotels in Greater CAIRo
}

\author{
By \\ Omnia Mohammed Hassan Mohammed Abd-Elfattah Elzohry \\ Master Researcher \\ Faculty of Tourism and Hotels \\ Mansoura University $\square$ \\ Ass. Prof of Hotel management \\ Faculty of Tourism and Hotels \\ Mansoura University $\square$
}

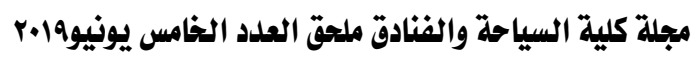

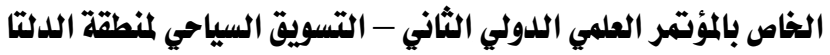


Strategic Planning for Human Resources in Hotels: A Field

- Study on a Sample of Five Star Hotels in Greater Cairo

STRATEgic PlanNing FOR HUMAN RESOURCES IN Hotels: A Field STUdy ON A SAMPle OF Five STAR Hotels in Greater Cairo

Omnia Mohammed Hassan ${ }^{2}$

Mohammed Abd-Elfattah Elzohry ${ }^{1}$

\section{Abstract}

This study was designed to explore the extent of applying strategic human resource planning process in five star Cairo hotels and its impact of on employee performance. In order to achieve this aim, a questionnaire form was developed and directed to a random sample of human resources officials in a five star Cairo hotels. A total of 100 questionnaires were distributed; only 94 forms $(94 \%)$ were valid. The extracted results indicated that the all hotels have a strategic plan to determine HR needs at the investigated hotels. There are managers in investigated hotel who have efficiency and high skill to accommodating strategic thinking. Applying one strategic plan on all departments is difficult. laws and legislation which relates on work law inside the country is stable. HR officials classified political and economic crisis which non setting in consideration during the strategic plan are the main threat in applying. Based upon the findings, some recommendations were suggested and directed to hotel managers.

Key Words: Human Resources, Strategic Planning, Human Resources Management, Action Plan. 


\section{التفطيط الاستراتيجي للهمارد البشرية في الفنادق :دراسة هيدانيه علي عينه هن فنادق الخمس نجوم بالقاهرة الكبرى}

صُهمهت هذه الدراسـة لاستكشاف مدى تطبيق عملية التخطيط الاستراتيجي للموارد البشريـة يِّ فنادق القاهرة من فئة الخمس نجوم وتأثيرها على أداء الموظفين بتلك الفنادق. مـن أجل تحقيق هذا الهدف ، تم تصميهم استمارة استبيـان وتوجيهها إلى عينـة عشوائية من مسئولي الموارد البشرية يخ فنادق الخمس نجوم بالقاهرة الكبري. تم

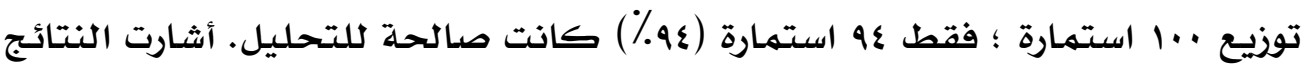
المستخلصدة إلى أن جميع الفنادق لديها خطة إستراتيجية لتحديد احتياجات الموارد البشريـة ِِِ الفنادق عينة الدراسـة. المديرين ِِّ تلك الفنادق يتمتعون بالكفاءة والمهارة العالية لاستيعاب التفكير الاستراتيجي. من الصعب تطبيق خطة استراتيجية واحدة على جميع الأقسام بالفندق. كما ان القوانين والتشريعات المتعلقة بقانون العمل داخل البلد مستقرة وذلك يساعد فى انتهاج منهج التخطيط الاستراتيجي. يصنف مسؤولو الموارد البشريـة الأزمـة السياسية والاقتصدادية التي لم يتم وضعها بالاعتبـار أثناء وضع الخطة الاستراتيجية هي التهديد الرئيسي اثناء تطبيق التخطيط الاستراتيجي. واستنادا إلى النتائج ، تم اقتراح بعض التوصيات وتوجيهها إلى مديري الفنادق. الكلمات الافتتاحية: صناعة الموارد البشرية ، التخطيط الاستراتيجي ، إدارة الموارد

\section{Introduction}

$$
\text { البشريـة ، خطة العمل. }
$$

Bdris (2012), described human resource planning (HRP) as a long permanent process that organized completely to hiring the HR effectively in the organization. Strategic human resource planning (SHRP) helps in forecasting and reducing turnover average of employees. This influential process motivates 
Strategic Planning for Human Resources in Hotels: A Field

- Study on a Sample of Five Star Hotels in Greater Cairo

employees to work and decreases the turnover average of employees (Philips and Moutinho, 2014). Hence, human resource planning (HRP) processes have to be more strategically in addition to design the future state of the establishment (Seymen, 2017). This study was going to investigate the subject of strategic human resource planning in five star hotels and its impact of on employee performance.

\section{Aim of the Study}

This study aims to determine the extent of applying strategic human resource planning process in five star Cairo hotels and its impact of on employee performance.

\section{Research questions}

1) To what extent hotels applied strategic planning in human resources functions?

2) how can hotel management designs a frame work for strategic planning?

3) what are the main steps that should be implemented to achieve strategic planning?

4) What are the strengthen, weakness points of applying strategic planning in human resources functions?

5) What are the opportunities, and threats of applying strategic planning in human resources functions?

\section{Research hypotheses}

This study have main hypothesis as follows:

- There is a significant effect on 0.05 degree on SWOT dimensions on applying strategic planning in human resource management's functions.

\section{Review of literature}

\section{An Overview of Human Resource Management(HRM)}

Bratton and Gold (2007) defined human resources management as combination of classic managerial personnel jobs with performance management, employee communication and 
resource planning. The most popular HRM practice within organizations refers to the employees within the organization and some firm that deals with hiring, training and other employee's issues (Ferguson and Reio, 2010).

Pinnington (2011) mention that HRM should ensure alignment among organization's mission, statement of policies and moral principles.adition to that, HRM must create a culture that adopt getting the right information to the right people at the correct time (Minbaeva, 2013). Also, HRM must nourish the "ultimate employee experience" by transform the tacit knowledge into clear knowledge; build employee skills, creating bench strength and competencies (Kaufman, 2014).also, HRM can realize effective knowledge sharing and usage into everyday life. It has the capabilities for measuring, creating and reinforcing the knowledge-sharing expectation (Taipale, 2016).

According to Hartel and Fujimoto (2010), HRM involves the management of the HR required by the organization and more over being certain that $\mathrm{HR}$ is maintained and acquired for objectives of promoting the organization's plan, objectives, and strategy. In other cases, HRM focus on securing, utilizing, and maintaining an effective labor force, which organizations demand for both their long term and short permanence in the market (Little, 2011).

Brewster (2009) specified core HRM jobs namely staffing, development and training, performance appraisal, compensation and benefits, and lastly union and employee relations and health and safety. In addition for HRM to realize its organizational goals, managers must perform a number of main jobs which perform what is often referring to as the management process (Bryson and Ryan, 2012).

\section{Human Resource Planning HRP as One of HRM Functions}

According to Curson et al., (2010), Human Resource Planning (HRP) as "the process for ensuring that the Human 
Resource $s$ requirements of an organization are identified and plans are made for satisfying those requirements". Snell and Bohlander (2011) had shown that Human Resources Planning (HRP) is "the strategically driven Human Resource Function will be devoted to finding ways to help the organization gain important advantages over its competitors". Human Resources Planning (HRP) is crucial to work success. Without it, there is a little chance of the work having the right employee at the right environment at the correct time doing the correct work (Amitabh, 2012).

Aslam et al., (2013) managed a research suggesting a number of important of Human Resource Planning (HRP). Planning is not as facile as one may think because it needs a concerted potential to come out with a system that would facile your labor. Commencing is complicated, however you start and complete it you have a smile because each thing moves smoothly. Planning is a process that has to be started from somewhere or completed for the objective. It embraces gathering data that would enable supervisors and managers make sound decisions. The data obtained is also used to make good actions for achieving the objectives of the establishment (Chapman, 2014).

The system does not assist the establishment only, but it will also easy the function planning of the employees and help them to achieve the aims as well. This augment motivation and the establishment would become a good environment to work. Human Resource Planning (HRP) forms an important side of Management information system (Inyang, 2011). HR have a huge task keeping speed with the all the changes and ensuring that the correct employees are available to the establishment at the correct time. It is changes to the structure of the labor force that force managers to pay interest in HR planning. The changes in structure of labor force not only impact the appointment of employees, but 
also the ways of training, selection, motivation and compensation (Aslam et al., 2013).

There are some circumstances in which Human Resourcing can be used in hotel industry. Armstrong (2009) specified that it should to determine the numbers to be employed at a new location. if hotels plus-do the size of their labor forces it would carry surplus or under-utilized employee Instead of that, if the opposite misjudgment is made, employees may be over worked, making it impossible to meet production and service the deadlines at the quality level predictable. Hotels going to Retaining highly skilled staff by Control the extent of resignation, Find the reasons for it, Organize what it is costing the organization, Compare waste rates with different similar establishments (Boella, 2010).

Sadly, human resource planning (HRP) has not often been successful; Bandt and Haines (2002) have recorded the following as obstacles to completely execution of human resource planning (HRP). Care of high management - for human resource planning (HRP) to be viable in the long run, it should have the complete support of at least one influential major executive. Size of initial effort - many human resource planning(HRP) programs fails because of an plus complicated initial effort, successful human resource planning (HRP)programs start gradually and slowly expand as they meet with success (Bandt and Haines, 2002; Zakaria, 2013). Integration with organizational plan - HR plans should be derived from organization's plans. The key here is to improve better communication channels between the HR planners and the organization planners (Ter Stege, 2014).

According to Dom et al., (2012), human resource planning process deals with the activities involve in it. The Structure and explanation below gives an overview of what goes into the planning process. Figure 1 shows this process in details as following below: 


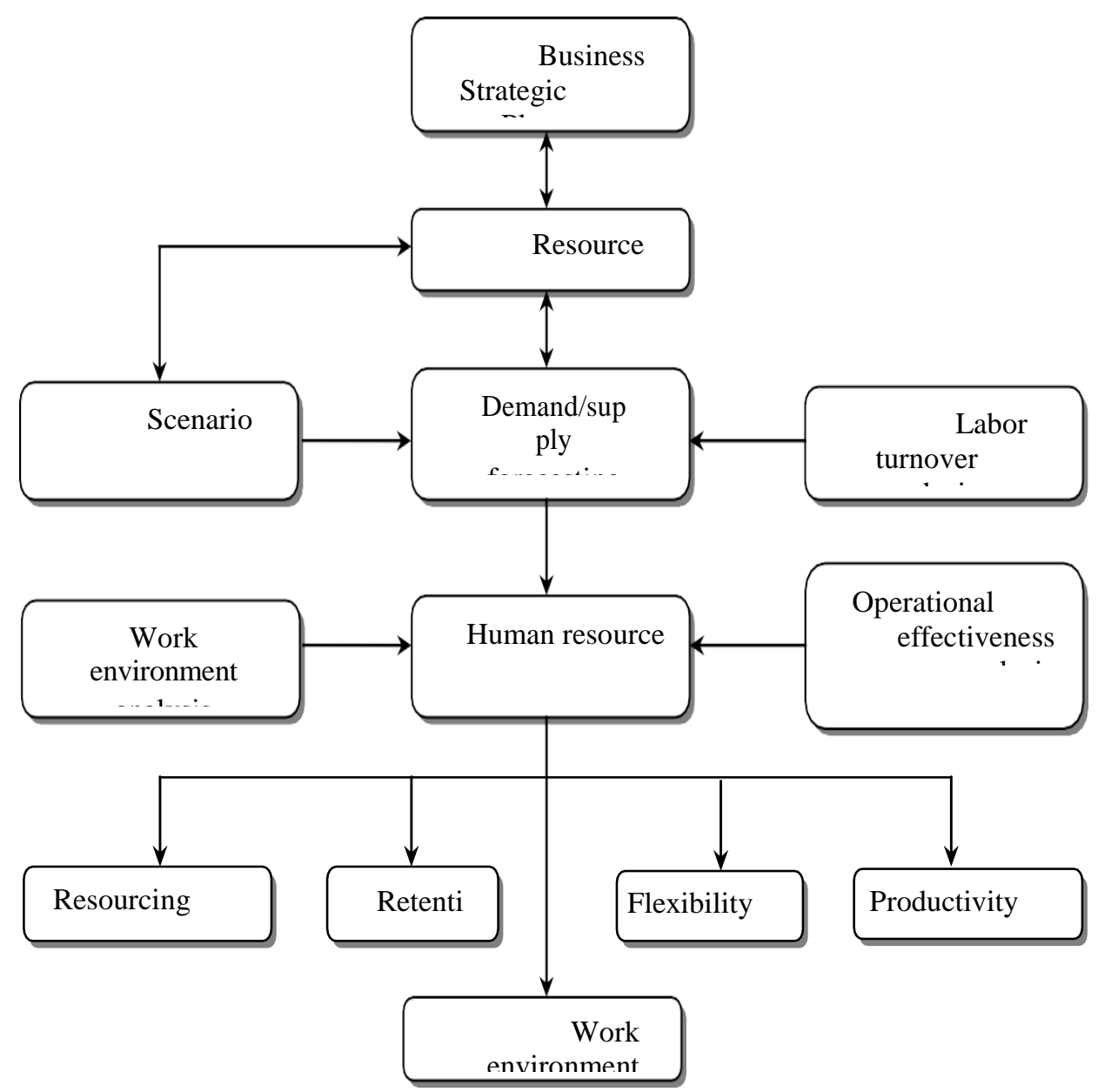

Figure 1: Process of Human Resource Planning Source: Dom et al., (2012)

Business strategic plans - defining future activity initiatives and levels demanding new skills.

Resource strategy - planning to archive competitor advantage by improving intellectual capital-employing, ensuring that they improve organization specific skills and knowledge, and taking step by step to become an ,employer of choice" . 


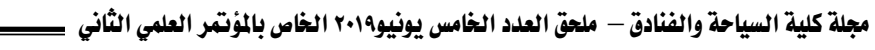

Scenario planning- estimating a plan where the establishment is going in its environment and the implications for HR requirements.

> Supply/Demand forecasting -assessing the future demand for employees, and assessing the number of employees likely to be available from within and outside the establishment.

Work turnover analysis - analyzing actual work turnover trends and figures as an input to supply forecasts (Dom et al., 2012).

\section{An Overview of Strategic Planning}

De Wit and Meyer (2010) known strategy as a plan or pattern that integrates the establishment's major objectives, action and policies sequences into a cohesive complete. Strategic management therefore oversees these facilitates and alignments the operations of moving from strategic planning to strategy implementation (Kearns, 2012). Strategy can be defined as depending on internal work resources, their fit in work environment objective setting and their application to internal abilities to respond to the market in which the work operates (Pretorius and Maritz, 2011; Stefanovic and Milosevic, 2012).

Strategic planning is the combination of planning and strategy. In other sides, it is the planning of strategy. Strategic planning was improved to help establishment respond and anticipate effectively to their dramatically changing environments (Patnaik, 2012). Blatstein (2012) described strategic planning as a particular kind of decision-making process having three advantages. Firstly, having something done in advance of taking behavior; that is, it is anticipatory decision making. It is the process of deciding what to do or how to do it before action is needed. Secondly, something needed when the desired future state embraces an interdependent set of decisions; that is, a system of decisions, which is too long to handle each at once and requires that earlier decisions be revised in the light of next decisions. And 
thirdly a process directed towards producing more or one future states, which are wanted and which are not expected to occur unless something is done.

According to Burke et al., (2010), establishments should to determine how far into the future they require to plan by at lower five contributing organizational factors, namely; Product life cycle, technological change, Lead-time, Present value, Organization life cycle.

According to Kamau (2008) as cited from Dancer et al., (2006) the issue-based (based -or goal) planning model extends from the main strategic planning model. The processes include:

\section{Internal/ external assessment to recognize}

strengths, weaknesses, opportunities and threats (SWOT)

2. Strategic analysis to priorities and identify goals/ major issues

3. Design major programs (or strategies) to address goals/ issues

4. Update vision /design, values and mission

5. Establish action plans (resource needs, objectives , responsibilities and roles for implementation)

6. Record issues, objectives, programs /strategies, updated vision and mission, and action plans in a Strategic Plan document, and attach SWOT, etc.

7. Improve the yearly Operating Plan document

8. Authorize and Develop budget for year one (allocation of funds required to fund year one)

9. Conduct the establishment's year-one operations

10. Review /monitor / update /evaluate Strategic Plan document

\section{Research Materials and Methods}

In order to achieve the research aim, HR officials in a five star Cairo hotels were surveyed. A total of 100 questionnaires were distributed randomly in the investigated hotels (20 hotels) during October to December 2018, only 94 forms (94\%) were valid to analyze. The questionnaire consisted of five dimensions. Dimensions are Strengthen points, weakness points, The 
opportunities, The threats, Mechanisms of implementing with 26 attributes. The respondents were asked to answer this question by using a five-point Likert-type scale (Strongly agree $=5$, agree $=4$, neutral $=3$, disagree $=2$ and strongly disagree $=1$ ) to determine the levels of agreement with the statements investigated the range of each level of agreement was calculated as follow:
$1=1: 1.80$
$2=1.81: 2.60$
$3=2.61: 3.40$
$4=3.41: 4.20$
$5=4.21: 5$

The Statistical Package for the Social Sciences (SPSS) version 24.0 was used to analyze and compute the collected data.

Reliability Analysis

Table 1: Alpha cronpach test

\begin{tabular}{|c|c|}
\hline Number of Statements & Alpha \\
\hline 26 & 0.72 \\
\hline
\end{tabular}

Table 1 indicated that alpha coefficient of the questionnaires dimensions was 0.72 (higher than 0.70). This result indicated to the reliability and validity of the questionnaires for using in the study.

\section{Results and Discussion}

The results involved two main stages. Descriptive analysis was used to discover participants' responses, and multiple regression analysis were conducted to examine the affect independent variables on dependent variable. The results obtained were computed and analyzed in the following tables.

Table (2): Demographic Data of HRD Officials.

\begin{tabular}{|c|c|c|c|c|}
\hline \multirow{2}{*}{$\begin{array}{l}\text { Demograph } \\
\text { ic Data }\end{array}$} & \multirow[t]{2}{*}{ Attribute } & \multicolumn{2}{|c|}{ Statistics } & \multirow[b]{2}{*}{ Rank } \\
\hline & & Freq & $\%$ & \\
\hline \multirow{2}{*}{ Gender } & Male & 78 & 830 & 1 \\
\hline & Female & 16 & 17.0 & 2 \\
\hline & Total & 94 & \multicolumn{2}{|c|}{$100 \%$} \\
\hline
\end{tabular}


Strategic Planning for Human Resources in Hotels: A Field

- Study on a Sample of Five Star Hotels in Greater Cairo

\begin{tabular}{|c|c|c|c|c|}
\hline Age & Less than 40 years & 67 & 71.3 & 1 \\
\hline & From $41-50$ years & 20 & 21.3 & 2 \\
\hline & More than 50 years & 7 & 7.4 & 3 \\
\hline & Total & 94 & & \\
\hline Educational & University Degree & 70 & 74.4 & 1 \\
\hline level & $\begin{array}{l}\text { Postgraduate } \\
\text { Degree }\end{array}$ & 24 & 25.6 & 2 \\
\hline & Total & 94 & & \\
\hline & Less than 5 years & - & - & 4 \\
\hline & From 5-10 years & 11 & 11.7 & 3 \\
\hline Years of & From $10-15$ years & 70 & 74.5 & 1 \\
\hline & More than 15 years & 13 & 13.8 & 2 \\
\hline & Total & 94 & & \\
\hline
\end{tabular}

As it can be observed from the previous table 2 that, among the 94 respondents, 78 respondents $(83 \%)$ were male, and 16 respondents $(17 \%)$ were female. The results refer to that the majority of HRD Officials in investigated hotels were male. This result may back to the desire of hotel management in hiring male employees due to the nature of hotel industry. According to age group, among the 94 respondents, $71.3 \%$ fell into the age group less than 40 years; this was followed by age group from 41 - 50 years by $21.3 \%$. The age group more than 50 years was the smallest group and presented by $7.4 \%$. This result indicates that the majority of hotel employees fall in youth category. With respect to the educational level variable, a high proportion of the tested sample (74.4\%) have a university degree, , this is followed by Investigated hotel employees with postgraduate degree which was the smallest group and presented by (25.6\%). According to employees' years of experience, among the 94 respondents, $74.5 \%$ have 10-15 years of experience; this was followed by group employees with more than 15 years of experience $(13.8 \%)$. The 
employees with 5-10 years of experience was the smallest group and presented by $11.7 \%$.

Table 3: Is there a strategic plan to determine your HR needs at the hotel?

\begin{tabular}{|c|c|c|}
\hline Answers & Freq. & \% \\
\hline Yes & 94 & $100 \%$ \\
\hline No & 0 & $0.0 \%$ \\
\hline Total & $\mathbf{9 4}$ & $\mathbf{1 0 0}$ \\
\hline
\end{tabular}

Results in table 3 clearly indicated whether there is a strategic plan to determine human resources needs at the investigated hotels or not. The data summarized in the table (3) showed that all of investigated managers $(100 \%)$ ensured that there is a strategic plan to determine your HR needs at their hotel.

Table 4: strengthen points

\begin{tabular}{|l|c|c|c|c|c|}
\hline \multicolumn{1}{|c|}{ Statement } & Mean & S.D & $\mathbf{C H I}^{\mathbf{2}}$ & $\begin{array}{c}\text { P- } \\
\text { value }\end{array}$ & $\mathbf{R}$ \\
\hline $\begin{array}{l}\text { 1. The senior management } \\
\text { supports the strategic } \\
\text { thinking of Human } \\
\text { resources planning }\end{array}$ & $\mathbf{3 . 7 3}$ & $\mathbf{1 . 0 5 9}$ & 74.18 & $* 0.000$ & $\mathbf{2}$ \\
\hline $\begin{array}{l}\text { 2. There are managers in } \\
\text { hotel who have efficiency } \\
\text { and high skill to } \\
\text { accommodating strategic } \\
\text { thinking. }\end{array}$ & $\mathbf{4 . 5 1}$ & $\mathbf{. 6 8 4}$ & 19.55 & $* 0.047$ & $\mathbf{1}$ \\
\hline $\begin{array}{l}\text { 3. Physical resources are } \\
\text { available to implement the } \\
\text { strategic plan. }\end{array}$ & $\mathbf{3 . 1 5}$ & $\mathbf{. 8 7 9}$ & 126.38 & $* 0.000$ & $\mathbf{4}$ \\
\hline $\begin{array}{l}\text { 4. There is data base for } \\
\text { human resources in the } \\
\text { hotel }\end{array}$ & $\mathbf{3 . 5 9}$ & $\mathbf{1 . 2 0 4}$ & 95.88 & $* 0.000$ & $\mathbf{3}$ \\
\hline 5. There are specific places & $\mathbf{2 . 6 7}$ & $\mathbf{1 . 2 3 9}$ & 106.12 & $* 0.000$ & \\
\hline
\end{tabular}


Strategic Planning for Human Resources in Hotels: A Field

- Study on a Sample of Five Star Hotels in Greater Cairo

\begin{tabular}{|l|l|l|l|l|}
\hline $\begin{array}{l}\text { to train employees on } \\
\text { strategic planning }\end{array}$ & & & & \\
\hline Average Mean & $\mathbf{5}$ \\
\hline
\end{tabular}

*Significant at $\mathrm{P} \leq 0.05, \mathbf{S} . \mathrm{D}=$ Standard deviation, $\mathrm{R}=\mathrm{Rank}$

Table 4 revealed that, there was a significant difference among respondents' answers $(\mathrm{p}<0.05)$. The general responses of employees were agreement with average mean 3.53. According to the results showed in Table 4 The respondents agreed on three statements from all statements which are arranged according to their means. The statement of " There are managers in hotel who have efficiency and high skill to accommodating strategic thinking" has got the highest percentage of agreement from the respondents at (Mean=4.51). The statement of " The senior management supports the strategic thinking of Human resources planning" at (Mean=3.73). The statement of " There is data base for human resources in the hotel" at (Mean=3.59).

Meanwhile, the responses of HR officials were neutral with two statements from all statements which are arranged according to their means. The statement of " Physical resources are available to implement the strategic plan." at (Mean=3.15). The statement of " There are specific places to train employees on strategic planning " at (Mean=2.67).

Table 5: Weakness points

\begin{tabular}{|l|c|c|c|c|c|}
\hline \multicolumn{1}{|c|}{ Statement } & Mean & S.D & $\mathbf{C H I}^{2}$ & $\begin{array}{c}\text { P- } \\
\text { value }\end{array}$ & $\mathbf{R}$ \\
\hline $\begin{array}{l}\text { 6. None of clarity of } \\
\text { strategic thinking concept } \\
\text { for managers }\end{array}$ & $\mathbf{2 . 9 5}$ & $\mathbf{. 9 2 0}$ & 53.17 & $* 0.001$ & $\mathbf{3}$ \\
\hline $\begin{array}{l}\text { 7. Lack of communication } \\
\text { between managers and } \\
\text { employees }\end{array}$ & $\mathbf{2 . 8 6}$ & $\mathbf{1 . 2 9 2}$ & 109.65 & $* 0.000$ & $\mathbf{4}$ \\
\hline $\begin{array}{l}\text { 8. None of consistency in } \\
\text { numbers and skills of the }\end{array}$ & $\mathbf{3 . 4 6}$ & $\mathbf{1 . 2 0 6}$ & 219.22 & $* 0.000$ & \\
\hline
\end{tabular}




\begin{tabular}{|c|c|c|c|c|c|}
\hline staff each all department & & & & & 2 \\
\hline $\begin{array}{l}\text { 9. Difficulty applying one } \\
\text { strategic plan on all } \\
\text { departments }\end{array}$ & 4.23 & 1.041 & 185.39 & $* 0.000$ & 1 \\
\hline $\begin{array}{l}10 . \quad \text { Non-cooperation } \\
\text { between different } \\
\text { departments in applying } \\
\text { stages of strategic plan }\end{array}$ & 2.54 & 1.529 & 223.06 & $* 0.000$ & 6 \\
\hline $\begin{array}{l}\text { 11. In case of applying } \\
\text { strategic plan the } \\
\text { employees may ask to } \\
\text { increase their wages }\end{array}$ & 2.78 & .805 & 148.28 & $* 0.000$ & 5 \\
\hline Average Mean & & & 3.14 & & \\
\hline
\end{tabular}

*Significant at $\mathrm{P} \leq 0.05, \mathbf{S} . \mathrm{D}=$ Standard deviation, $\mathrm{R}=\mathrm{Rank}$

Table 5 revealed that, there was a significant difference among respondents' answers $(\mathrm{p}<0.05)$. The general responses of employees were neutral with average mean 3.14.

According to the results showed in Table 5 The respondents agreed on two statements from all statements which are arranged according to their means as follows:

- The statement of " Difficulty applying one strategic plan on all departments" has got the highest percentage of agreement from the respondents at $(\mathrm{Mean}=4.23)$.

- The statement of " None of consistency in numbers and skills of the staff each all department" at (Mean=3.46).

Meanwhile, the responses of HR officials were neutral with three statements from all statements which are arranged according to their means as follows:

- The statement of " None of clarity of strategic thinking concept for managers" at (Mean=2.95).

- The statement of " Lack of communication between managers and employees " at (Mean=2.86). 
- The statement of " In case of applying strategic plan the employees may ask to increase their wages " at (Mean=2.78).

On other hand, the respondents disagreed on one statements from all statements as follows:

- The statement of " Non-cooperation between different departments in applying stages of strategic plan" at (Mean=2.54).

Table 6: The opportunities

\begin{tabular}{|c|c|c|c|c|c|}
\hline Statement & $\begin{array}{c}\text { Mea } \\
\text { n }\end{array}$ & S.D & $\underset{2}{\mathbf{C H I}}$ & $\begin{array}{c}\text { P- } \\
\text { value }\end{array}$ & $\mathbf{R}$ \\
\hline $\begin{array}{l}\text { 12. Academic institutions } \\
\text { (colleges -institutes) } \\
\text { provide qualified and } \\
\text { trained graduates to work } \\
\text { in hotels }\end{array}$ & 3.10 & $\begin{array}{r}1.18 \\
3\end{array}$ & $\begin{array}{r}178 . \\
03\end{array}$ & $\begin{array}{r}* 0.00 \\
0\end{array}$ & 4 \\
\hline $\begin{array}{l}\text { 13. The Stability of } \\
\text { country economic status } \\
\text { which helps on applying } \\
\text { strategic plan and non- } \\
\text { changing it for long time }\end{array}$ & 3.46 & $\begin{array}{r}1.09 \\
4\end{array}$ & $\begin{array}{r}112 . \\
83\end{array}$ & $\begin{array}{r}* 0.00 \\
0\end{array}$ & 2 \\
\hline $\begin{array}{l}\text { 14. Other hotel competition } \\
\text { are not interested in } \\
\text { applying strategic plan for } \\
\text { human resource }\end{array}$ & 3.26 & $\begin{array}{r}1.23 \\
5\end{array}$ & $\begin{array}{r}99.1 \\
7\end{array}$ & $\begin{array}{r}* 0.00 \\
0\end{array}$ & 3 \\
\hline $\begin{array}{l}\text { 15. The Stability of laws } \\
\text { and legislation which } \\
\text { relates on work law inside } \\
\text { the country }\end{array}$ & 3.85 & $\begin{array}{r}1.12 \\
6\end{array}$ & $\begin{array}{c}78.4 \\
4\end{array}$ & $\begin{array}{c}* 0.00 \\
0\end{array}$ & 1 \\
\hline $\begin{array}{l}\text { 16. There are specialized } \\
\text { expertise companies in } \\
\text { setting strategic plan for } \\
\text { the hotel }\end{array}$ & 1.77 & $\begin{array}{r}1.04 \\
1\end{array}$ & $\begin{array}{c}162 . \\
10\end{array}$ & $\begin{array}{c}* 0.00 \\
0\end{array}$ & 5 \\
\hline Average Mean & \multicolumn{5}{|c|}{3.09} \\
\hline
\end{tabular}

*Significant at $\mathrm{P} \leq 0.05, \mathbf{S} . \mathrm{D}=$ Standard deviation, $\mathrm{R}=\mathrm{Rank}$ 
Table 6 revealed that, there was a significant difference among respondents' answers $(\mathrm{p}<0.05)$. The general responses of employees were neutral with average mean 3.09. According to the results showed in Table 6 The respondents agreed on two statements from all statements which are arranged according to their means as follows:

- The statement of " The Stability of laws and legislation which relates on work law inside the country " has got the highest percentage of agreement from the respondents at $(\mathrm{Mean}=3.85)$.

- The statement of "The Stability of country economic status which helps on applying strategic plan and non-changing it for long time" at (Mean=3.46).

Meanwhile, the responses of HR officials were neutral with two statements from all statements which are arranged according to their means as follows:

- The statement of "Other hotel competition are not interested in applying strategic plan for human resource" at (Mean=3.26).

- The statement of " Data is collected from employees about their training needs before prepare training courses for them " at (Mean=3.10).

On other hand, the respondents disagreed on one statements from all statements that " There are specialized expertise companies in setting strategic plan for the hotel" at $($ Mean $=1.77)$.

Table 7: The Threats

\begin{tabular}{|l|c|c|c|c|c|}
\hline \multicolumn{1}{|c|}{ Statement } & $\begin{array}{c}\text { Mea } \\
\mathbf{n}\end{array}$ & S.D & $\mathbf{C H I}^{\mathbf{2}}$ & $\begin{array}{c}\text { P- } \\
\text { value }\end{array}$ & $\mathbf{R}$ \\
\hline $\begin{array}{l}\text { 17. Increasing the } \\
\text { declaration fees of staying } \\
\text { for foreign employees in } \\
\text { hotels }\end{array}$ & $\mathbf{3 . 9 8}$ & $\mathbf{. 9 6 1}$ & 113.2 & $* 0.00$ & \\
$18 . \quad$ Increasing the & $\mathbf{3 . 3 1}$ & $\mathbf{1 . 0 2}$ & 79.34 & $* 0.00$ & 0 \\
\hline
\end{tabular}


Strategic Planning for Human Resources in Hotels: A Field

\begin{tabular}{|c|c|c|c|c|c|}
\hline $\begin{array}{l}\text { competition between the } \\
\text { hotels to recruitment } \\
\text { qualified employees }\end{array}$ & & 7 & & 0 & 4 \\
\hline $\begin{array}{l}\text { 19. Determination the } \\
\text { country the minimum } \\
\text { wages for employees }\end{array}$ & 2.29 & $\begin{array}{r}1.07 \\
4\end{array}$ & $\begin{array}{c}224.6 \\
7\end{array}$ & $\begin{array}{c}* 0.00 \\
0\end{array}$ & 5 \\
\hline $\begin{array}{l}\text { 20. Changing the laws } \\
\text { which relates on the } \\
\text { insurance and pensions }\end{array}$ & 3.47 & .876 & \begin{tabular}{|c}
176.7 \\
8
\end{tabular} & $\begin{array}{c}* 0.00 \\
0\end{array}$ & 3 \\
\hline $\begin{array}{l}\text { 21. Political and economic } \\
\text { crisis which non setting in } \\
\text { consideration during the } \\
\text { strategic plan }\end{array}$ & 4.01 & $\begin{array}{r}1.37 \\
2\end{array}$ & 55.46 & $\begin{array}{c}* 0.00 \\
2\end{array}$ & 1 \\
\hline
\end{tabular}

*Significant at $\mathrm{P} \leq 0.05, \mathbf{S} . \mathrm{D}=$ Standard deviation, $\mathrm{R}=\mathrm{Rank}$

Table 7 revealed that, there was a significant difference among respondents' answers $(\mathrm{p}<0.05)$. The general responses of employees were agreement with average mean 3.41. According to the results showed in Table 7 The respondents agreed on three statements from all statements which are arranged according to their means as follows:

- The statement of "Political and economic crisis which non setting in consideration during the strategic plan" has got the highest percentage of agreement from the respondents at (Mean=4.01).

- The statement of " Increasing the declaration fees of staying for foreign employees in hotels" at (Mean=3.98).

- The statement of "Changing the laws which relates on the insurance and pensions" at (Mean=3.47).

Meanwhile, the responses of HR officials were neutral with one statements from all statements that " Increasing the competition between the hotels to recruitment qualified employees" at (Mean=3.31). On other hand, the respondents disagreed 
on one statements from all statements that " Determination the country the minimum wages for employees" at (Mean=2.29).

Table 8: mechanisms of implementing

\begin{tabular}{|l|l|l|l|l|l|}
\hline \multicolumn{1}{|c|}{ Statement } & Mean & S.D & $\mathbf{C H I}^{\mathbf{2}}$ & $\begin{array}{c}\text { P- } \\
\text { value }\end{array}$ & $\mathbf{R}$ \\
\hline $\begin{array}{l}\text { 22. Planners are committed } \\
\text { to do swot analysis before } \\
\text { preparing of the strategic } \\
\text { plan for the human } \\
\text { resources in the hotel }\end{array}$ & $\mathbf{3 . 7 7}$ & $\mathbf{1 . 2 3 9}$ & 234.76 & $* 0.000$ & $\mathbf{2}$ \\
\hline $\begin{array}{l}\text { 23. The planners are } \\
\text { committed the preparing of } \\
\text { the strategic plan by setting } \\
\text { strategic objectives to the } \\
\text { result of SWOT analysis }\end{array}$ & $\mathbf{3 . 7 6}$ & $\mathbf{. 9 6 9}$ & 105.02 & $* 0.000$ & \\
\hline $\begin{array}{l}\text { 24. There are an available } \\
\text { mechanisms and methods } \\
\text { which are used to achieve } \\
\text { desired objectives (i.e., } \\
\text { action plan) }\end{array}$ & $\mathbf{4 . 3 4}$ & $\mathbf{1 . 0 0 1}$ & 98.70 & $* 0.000$ & $\mathbf{3}$ \\
\hline $\begin{array}{l}\text { There are indicators for } \\
\text { measurement level of } \\
\text { success in hotel action plan }\end{array}$ & $\mathbf{3 . 1 0}$ & $\mathbf{1 . 0 3 8}$ & 100.58 & $* 0.000$ & \\
\hline $\begin{array}{l}\text { 26. The action plan is } \\
\text { available the persons for } \\
\text { implementationlthe time } \\
\text { lavailable } \\
\text { resources in action plan }\end{array}$ & $\mathbf{2 . 4 8}$ & $\mathbf{1 . 2 5 9}$ & 156.22 & $* 0.000$ & $\mathbf{5}$ \\
\hline Average Mean & & & & \\
\hline
\end{tabular}

*Significant at $\mathrm{P} \leq 0.05, \mathbf{S} . \mathrm{D}=$ Standard deviation, $\mathrm{R}=\mathrm{Rank}$

Table 8 revealed that, there was a significant difference among respondents' answers $(\mathrm{p}<0.05)$. The general responses of 
employees were agreement with average mean 3.49. According to the results showed in Table 8 The respondents agreed on three statements from all statements which are arranged according to their means as follows:

- The statement of " There are an available mechanisms and methods which are used to achieve desired objectives (i.e., action plan)" has got the highest percentage of agreement from the respondents at (Mean=4.34).

- The statement of "Planners are committed to do SWOT analysis before preparing of the strategic plan for the human resources in the hotel" at (Mean=3.77).

- The statement of "The planners are committed the preparing of the strategic plan by setting strategic objectives to the result of SWOT analysis" at (Mean=3.76).

Meanwhile, the responses of HR officials were neutral with one statement from all statements that " There are indicators for measurement level of success in hotel action plan " at (Mean=3.10). On other hand, the respondents disagreed on one statement from all statements that " The action plan is available the persons for implementation $\backslash$ the time lavailable financial resources in action plan" at (Mean= 2.48).

Table 9: Testing hypothesis

\begin{tabular}{|c|c|c|c|c|}
\hline SOWT & $\begin{array}{c}\text { Parameters of } \\
\text { Regression } \\
\text { (B) }\end{array}$ & T-test & p-value & Rank \\
\hline (Constant) & $\mathbf{- 2 . 2 5 7}$ & $\mathbf{- 1 . 4 9 8}$ & $\mathbf{. 1 3 4}$ & \\
\hline $\begin{array}{c}\text { Strengthen } \\
\text { points }\end{array}$ & .153 & 3.681 & .000 & $\begin{array}{c}\text { The } \\
\text { third }\end{array}$ \\
\hline Weakness points & .251 & 3.863 & .033 & $\begin{array}{c}\text { The } \\
\text { second }\end{array}$ \\
\hline
\end{tabular}




\begin{tabular}{|c|c|c|c|c|}
\hline \hline $\begin{array}{c}\text { The } \\
\text { Opportunities }\end{array}$ & .073 & 1.686 & .009 & $\begin{array}{c}\text { The } \\
\text { fourth }\end{array}$ \\
\hline The threats & .514 & 10.781 & .000 & $\begin{array}{c}\text { The } \\
\text { first }\end{array}$ \\
\hline
\end{tabular}

* = significant at $\mathrm{P} \leq 0.05$

It is noticed from table 9, that the values of the Parameters of Regression are less than 0.05 .. Therefore, hypothesis zero could be rejected and it would be accept alternative hypothesis (H1) that there are significant effect on 0.05 degree for SWOT on taking the decision of applying strategic planning in human resource management's functions. Factors ranked as follow:

1. The threats $(0.541)$

2. Weakness points $(0.251)$

3. Strengthen points $(0.153)$

4. The opportunities $(0.073)$

\section{Recommendations}

Based on researcher reading on the topic of the study "strategic planning" and the results that extracted from the field study, the following recommendations could be suggested to hotel senior managers:

1) Building a strategy when setting a HR planning is very significant. Therefore, it should be providing a specific places to train employees on strategic planning.

2) It recommended to set various scenarios during set the strategic plan which be suitable for each department based on the characteristics of its employee.

3) Before setting the strategic plan it should be ensure that there is a consistency in numbers and skills of the staff each all department.

4) Hotel management must find a way to contact with the ministry of planning in order to benefit from experts in the Ministry or sending hotels' managers specially HR officials to take a specific 
Strategic Planning for Human Resources in Hotels: A Field

= Study on a Sample of Five Star Hotels in Greater Cairo

training courses in strategic planning and to know how they can set an action plan.

5) Setting alternative scenarios that appropriate with crisis can reduce the risk of political and economic crisis that maybe happen and which not sets in consideration during the strategic plan.

6) It supposed to ensure that action plan includes all information needed, such as; persons for implementationlthe time lavailable financial resources in action plan.

${ }^{1}$ Ass. Prof of Hotel management Faculty of Tourism and Hotels Mansoura University

${ }^{2}$ Master Researcher Faculty of Tourism and Hotels Mansoura University

\section{References}

- Amitabh, S. (2012). Planning human resource: A key to the success of an organization. Indian journal.com, 56(3), 257-264.

- Armstrong, M. (2009) Armstrong's Handbook of Human Resource Management Practice. 11th edn. UK: Kogan Page.

- Aslam, M., Aslam, H. D., and Ali N., (2013) " human resource Planning in Managing human resource: A literature Review", International Journal of Human Resource Studies, Vol. 3, No. 1 pp. 200-212

- Bandt, A. and Haines, S. (2002) Successful strategic human resource planning: Systems Thinking Press.

- Bdris, P. (2012), "Strategic management in a hotel", Unpublished Bacelor Thesis, Finland: Saimaa University of Applied Sciences.

- Blatstein, I.M. (2012). Strategic planning: Predicting or shaping the future? Organization Development Journal, 30(2), 31-38.

- Boella, M. J. (2010). Human resource management in the hospitality industry (12th ed.(Cheltenham: Stanley Thorners.

- Bratton, J., \& Gold, J. (2007). Human Resources Management: Theory and Practice. Galgrave: McMillan.

- Brewster, C., (2009). Comparing HRM policies and practices across geographical borders In G.K. Stahl, \& I. Bjorkman, (Eds.), Handbook of 
Research in International Human Resource Management, Edward Elgar, Cheltenham, UK.

- Bryson, J., \& Ryan, R. (2012). Human resource management in the workplace. New Zealand: Pearson Education New Zealand Limited.

- Burke, A., Fraser, S., \& Greene, F.J. (2010). The multiple effects of business planning on new venture performance. Journal of Management Studies, 47(3), 391-415.

- Chapman, S. (2014). Scenario Planning for Human Resources and Strategic Workforce Planning. The Conference Board.

- Curson, J. Dell, M., Wilson, R., Bosworth, D. \& Baldauf, B. (2010). Who does workforce planning

- Dancer, O., Tatoglu, E. \& Glaister, K. (2006). The Strategic Planning Process in the Management of Tourism. Tourism Management, 11(3), 206- 213.

- De Wit, B., \& Meyer, R. (2010). Strategy: process, content, context an international perspective 4th edn. Hampshire, UK: Cengage Learning EMEA.

- Dom, N. Kasim, N. \& Shamsuddin, A. (2012). Framework of human resource planning (HRP) influencing factors for local workforce supply in Malaysian construction industry. Journal of Technology Management in China, 7(2), 177-197.

- Ferguson, K. L., \& Reio Jr, T. G. (2010). Human resource management systems and firm performance. Journal of Management Development, 29(5), 471-494.

- Hartel, C. E. J., \& Fujimoto, Y. (2010). Human resource management (2nd ed.). Frenchs Forest, N.S.W.: Pearson Australia.

- Inyang, B. J. (2011). Creating value through people: Best human resource (HR) practices in Nigeria. International business and management, 2(1), 141-150.

- Kamau, F. (2008). Strategic Planning Practices Adopted by Tour and Travel firms in Kenya. Unpublished MBA Thesis. Nairobi. University of Nairobi.

- Kaufman, B., (2014). "The Development of Human Resource Management across Nations: Unity and Diversity", Edward-Elgar, Cheltenham.

- Kearns, P. (2012). HR Strategy: Business Focused Individually Centred. Taylor \& Francis. 
Strategic Planning for Human Resources in Hotels: A Field

- Study on a Sample of Five Star Hotels in Greater Cairo

- Little, G. R. (2011). The role of human resources management in the modern organization. Auckland, N.Z.: Self Help Guides.

- Minbaeva, D.B. (2013). "Strategic HRM in building micro-foundations of organizational knowledge-based performance". Human Resource Management Review, 23, pp. 378-390

- Patnaik, R. (2012). Strategic planning through complexity: Overcoming impediments to forecast and schedule. Journal of Business Strategy, 9(1), 27-36.

- Phillips, P. and Moutinho, L., (2014) " Critical review of strategic planning research in hospitality and tourism", Tourism Research 48 (1) 96-120

- Pinnington, A.H., (2011). "Strategic Management and HRM", Chapter 1 in Harzing, A. \& Pinnington, A.H. (eds). International Human Resource Management, Sage, London, pp. 13- 46.

- Pretorius, M., \& Maritz, R. (2011). Strategy making: the approach matters. Journal of Business Strategy, 32(4), 25-31

- Seymen (2017), "Evolution of Strategic human resource management \& its application in selected hotels in Turkey", Worldwide Journal of Multidisciplinary Research and Development , 3 (2), pp. 61- 67

- Snell S. and Bohlander, G. (2011) Managing Human Resources, 16th Edition: Cengage Learning.

- Stefanovic, I., \& Milosevic, D. (2012). On conceptual differentiation and integration of strategy and business model. ZbornikradovaEkonomskogfakulteta u Rijeci: časopiszaekonomskuteorijuipraksu, 30(1), 141-161

- Taipale A. $(r \cdot 17)$ " From Administrative to Strategic Human Resource Management: A Case Study of Factors Affecting the Transformation", Published Master thesis, Aalto university of science and technology, Finland.

- Ter Stege, E. M. N., (2014), " Implementing strategic human resource planning: A case study at the municipality of Winterswijk", Published Master thesis, University of Twente, Holland

- Zakaria N., ( 2013) " HR Strategy Planning and Implementation Process: A case-study of the banking sector in Pakistan", Published Doctoral thesis, The University of Leeds. 